\title{
An Exploratory Model of Competitive Advantage through Dynamic Capabilities and Differentiation Approach for Knowledge-Based Companies
}

\author{
Alireza Abdolhosseini Khaligh ( $\square$ arkhaligh@ut.ac.ir) \\ University of Tehran Faculty of Management \\ Mohammad Haghighi \\ University of Tehran Faculty of Management \\ Mohsen Nazari \\ University of Tehran Faculty of Management \\ Hamid Khodadad Hosseini \\ Tarbiat Modares University Faculty of Management and Economics
}

\section{Research}

Keywords: Competitive Advantage, Competency, Dynamic Capabilities, Strategic Management, Differentiation, Knowledge-based Strategies.

Posted Date: July 17th, 2020

DOl: https://doi.org/10.21203/rs.3.rs-42614/v1

License: (9) (1) This work is licensed under a Creative Commons Attribution 4.0 International License. Read Full License 


\title{
An Exploratory Model of Competitive Advantage through Dynamic Capabilities and Differentiation Approach for Knowledge-based Companies
}

\author{
Alireza Abdolhosseini Khaligh \\ PhD Candidate of Business Administration, Alborz Campus, University of Tehran, Tehran, Iran \\ arkhaligh@ut.ac.ir; arkhaligh@alum.sharif.edu \\ Mohammad Haghighi \\ Associate Professor, Faculty of Management, University of Tehran, Tehran, Iran \\ mhaghighi@ut.ac.ir \\ Mohsen Nazari \\ Associate Professor, Faculty of Management, University of Tehran, Tehran, Iran \\ mohsen.nazari@ut.ac.ir \\ Hamid Khodadad Hosseini \\ Professor, Faculty of Management and Economics, Tarbiat Modares University, Tehran, Iran \\ khodadad@modares.ac.ir
}

Correspondence: Alireza Abdolhosseini Khaligh, University of Tehran-Alborz Campus, Tehran, Iran. E-mail: arkhaligh@ut.ac.ir, ar.khalig@gmail.com

\begin{abstract}
The competitive struggles in high-tech environment have featured the necessity to infer how competitive advantage is gained. Dynamic capabilities emphasize the nature of future competition, acceleration in innovation growth, and the role of strategic management in adaption, integration, and reconfiguration of organizational skills, resources, and competences toward shifting environment. This inquiry is based on an inductive approach. The qualitative research is primarily started with exploratory purpose through grounded theory strategy. Then, it is continued with quantitative type of study, explanatory and descriptive purposes through survey and correlational research strategies. The probe concepts and variables are analyzed in 30 top knowledge-based companies of Iran working on electronics and informatics field. The results indicate that achieving knowledge-centricity main phenomenon through dynamic capabilities requires presence of value creation on the basis of resource orientation together with competences. The knowledge-based companies can reach the summit and sustainable success in the knowledge-centricity main phenomenon when they consider two specialized paths related to the differentiation and knowledge-based strategies. Environmental cognition, knowledge management, knowledge approaches, branding and brand management, and strategic agility are identified with a positive and significant effect on both strategies.
\end{abstract}

Keywords: Competitive Advantage; Competency; Dynamic Capabilities; Strategic Management; Differentiation; Knowledge-based Strategies.

\section{Introduction}

The firms' principle query in the field of strategic management is how to obtain and sustain competitive advantage. Confronting this challenge can be pursued by the dynamic capabilities approach, which opens the way for firms to 
analyze the sources of value creation. This approach is related to rivalry based on innovation, competition in pricing policies, optimization of performance, augmentation of returns, and creative alteration of preceding competences. With this approach, corporate-level success or failure can be justified. Reviewing accepted theories in strategic management exposes competitive conditions that can reflect competitive strategy. Despite the fact that many theories have been promoted during past three decades in the context of competitive advantage sources, only a few constructed theoretical frameworks have been configured. Capabilities are the skills of a firm to coordinate and employ resources efficiently. A capability can enable a company to produce unique and creative products and services. The organizational capability is regarded as the ability to change and accept financial, technological and strategic evolution. The firm's competences are made through coming the capabilities together. The core competences are those competences by which the company can do things that the others are not able to do. Having these competences makes it easier to attain the competitive advantage. In this study, the researchers make an effort to achieve a novel perspective of gaining competitive advantage for a knowledge-based product or service through dynamic capabilities. The concept of dynamic capabilities supplements the fundamental proposition of the resourcebased viewpoint of the company as a great and effective vigor. The dynamic capability is a ability beyond operational competence that not only enables companies to originate and invent, but also leads to profitable innovations. The universal competitive combats in high tech and knowledge-based companies have clearly revealed the necessity for an augmented paradigm to know how competitive advantage is obtained. In international markets, successful firms are able to demonstrate convenient responsiveness and product innovation, coupled with knowledge-based strategies to make customers not only buy a brand but also make them pull towards a differentiated product or service. Under this term, one knowledge-based company is able to coordinate and rearrange internal and external competences towards competitive advantage through dynamic capabilities.

\section{Research Literature, Frameworks and Scope}

\subsection{Literature}

\subsubsection{Competitive Advantage}

Competitive advantage is ordinarily measured in three ways; some researches have been measured it by subjective indicators (Griffith, Noble, \& Chen, 2006), while some others have used objective measures (Zhang, 2007). In addition, a number of other researches have utilized a combination of objective and subjective measures (Morgan, Vorhies, \& Mason, 2009). The reputation has an important role in value creation and competitive advantage (Sheehan \& Stabell, 2010). A company achieves competitive advantage when it creates more value for the customers than competitors, so that the customers find that company's products and services better than the competitors. Creating value can be achieved through the supply of products and services with lower price or higher quality or more benefits. Competitive advantage is measured in terms of cost, quality, competence and speed (Ambe, 2010). The dimensions of employee empowerment have a significant positive effect on competitive advantage (Safari Kahreh, Ahmadi, \& Hashemi, 2011). Strategic leadership capabilities affect competitive advantage (Mahdi \& Almsafir, 2014). Competitive advantage is identified as the rate of return higher than average (Wang \& Ahmed, 2007; Eriksson, 2014). In terms of performance, competitive advantage can operate alone or in a combination of multiple advantages interacting with each other as an integrated entity. In first case, it is considered as the sustainable competitive advantage; and in connection with time, it has a long-lasting function time and easily accessible by competitors. (Kumar et al., 2015). Dynamic competitive advantage is the advantage that makes companies do their business more efficiently and effectively than competitors. It is generally based on the knowledge and organizational capabilities (Davcik \& Sharma, 2016). The concept of competitive advantage is directly related to the customer's desired values (Evans, 2016). The structure and degree of rivalry influence directly the international development strategies of corporations. Competition in a global level generates new conditions of communications, and also a new level of quality in technological advance and new ways of gaining competitive advantage. One significant solution that leads to increase the enterprise efficiency is collaboration on business, globalization and knowledge. Interorganizational relations are the source of competitive advantage for contemporary companies (Rzepka, 2017). Resources and capabilities along with strategies clarify competitive advantage, but their relevance and importance vary for each type of enterprise (Lorenzo, Rubio, \& Garcés, 2018). Innovation is the strategic tool in the competition for improvement, creation, and strengthening of business to create competitive advantage (Distanont \& Khongmalai, 2018). IT strategy and IT structure have a direct effect on competitive advantage (Saeidi et al., 2019).

\subsubsection{Dynamic Capabilities}

Dynamic capabilities empower business enterprises to make, deploy, and save the intangible assets which help the long-run businesses for high performance (Teece, 2007). Dynamic capabilities refer to the ability of a company or an organization to create manufacturing and service processes of new products in order to respond quickly to 
environmental changes (Helfat et al., 2009). Those are the company's ability to reconfigure assets and existing capabilities to achieve long-term competitive advantage (O'Reilly III \& Tushman, 2008). Helfat and Peteraf (2009) consider dynamic capability as the capacity of a firm to definitively create, extend, and qualify its resource base. Barrales-Molina et al. (2010) identify these capabilities as the ability of a company to integrate, build, and reconfigure internal and external skills in order to respond quickly to dynamic environments. Dynamic capabilities are noticed as problem-solving patterns whose main promotion gates are learning and organizational governance sustainability (P.-Y. Lee, Chen, \& Shyr, 2011). Dynamic capabilities have been proposed as a means of removing turbulent environments with the help of managers to expand, refine, and reproduce existing operational capabilities to new ones compatible with the environment (Pavlou \& El Sawy, 2011). A study conducted by Ellonen et al. (2011) indicates that dynamic capabilities consist of sensing, seizing and reconfiguring impact on the development of market and technological capabilities. Rodenbach and Brettel (2012) imply that these capabilities are defined to alter, expand and restructure the company's strategic assets. Jantunen et al. (2012) suggest that dynamic capabilities are the higher-order capabilities to modify operational and learning capabilities in new domains, and are therefore crucial for innovation activities. Dynamic capability is the ability to integrate, build and rebuild internal and external segments, as well as the ability to alter the operations and adapt to the dynamic change (M. Wang \& $\mathrm{Li}, 2013$ ). They expand the resource-based view (RBV) concentrating on special capabilities, which can be measured based on the benefits acquired through communications (Cheng, Chen, \& Huang, 2014). Many researchers consider dynamic capabilities as a process related to the ability of organizations in reconfiguring the resource bases. They confirm that dynamic capabilities get the organization to be involved with its resources in order to reform the operational capabilities and find new capabilities which lead to competitive advantage (Masteika \& Čepinskis, 2015). Dynamic capabilities are those organizational capabilities that allow companies to profit from producing differentiated products and services and manage the production of those which address new and existing market demands. Strong dynamic capabilities enable enterprises to produce not only the best type of product or service but also something that is unique and valuable (Pundziene \& Teece, 2016). For developing dynamic capabilities, it is suggested that firms improve the connections among their employees and empower their innovative potential. High-quality relationships and dialogue allow participants to advance and accept proposals for change even in the presence of conflicting viewpoints, and enhance the capacity to be flexible with market alterations (Salvato \& Vassolo, 2018). According to dynamic capabilities theory, entrepreneurs are more capable of sensing, seizing and reconfiguring resources and opportunities in vibrant entrepreneurial ecosystems (Roundy \& Fayard, 2018). Dynamic capabilities are more in the sense that organizations not only adapt to the business environment, but are mostly used to form it in many cases. These capabilities are part of a system that includes resources and strategy. The dynamic capabilities framework has been made to help organize and prioritize the infinite stream of competing and conflicting information that cascades toward managers as they try to gain competitive advantage. These capabilities specify what the company can do and how impressively it is able to make changes (David J Teece, 2018b).

\subsubsection{Differentiation Approach}

Differentiation is one of the main factors influencing one's desire to be identified by the unique brands and organizations (Bhattacharya \& Sen, 2003). When one individual tends to be identified by the brand, differentiation in the brand will be the chief factor in its selection (Berger \& Heath, 2007). In technology service organizations (TSOs), the differentiation strategy and operational independence have been examined in the process of innovation and the results reveal that they have a positive impact on the innovation process (Das \& Joshi, 2007). According to the theory of being unique, the need for differentiation and being unique is one of the key elements of an individual's motivation to create a good sense of self (J. A. Berger et al., 2005). Emotions play an important role in the consumer's choice structure, which complicates the task of creating a differentiated marketing strategy. It means that suppliers need to give more consideration to consumers' self-awareness (Barrena \& Sánchez, 2009). Differentiation has a significant impact on the prices and profits of one company to the extent that having more competitive advantage is useful to retain and intensify the differentiation advantage against competitors ((Rong et al., 2013). Differentiation approach has a positive impact on contemporaneous performance of an organization that allows a firm to maintain its current performance in the future. The differentiation strategy is also associated with greater systematic risk (Banker et al., 2014). The differentiation strategy affects profitability and organizational growth. Choosing a differentiated and direct-to-consumer distribution channel can positively help the company to increase gross profit margin and growth rate of the organization (Newton, Gilinsky Jr, \& Jordan, 2015).

\subsubsection{Knowledge-based Companies}

Knowledge is regarded as an advantage for knowledge-based companies in such a way that the companies are constantly updating their knowledge in order to be at least equal to their competitors (Wiklund \& Shepherd, 2003). 
By acknowledging the significance of science and technology in economic development, its logical consequence, namely the great importance of production capacity creation and innovation by knowledge-based companies becomes more apparent (Etzkowitz, 2006). Knowledge-based companies are deduced from the view on the basis of valuing the new opportunities connected to the knowledge-based economy and valuing the opportunities of the classical economy in a new way with emphasis on the importance of knowledge (Nicolescu, 2006). Three groups of individual, corporate and environmental factors influence the growth of new knowledge-based companies. Individual factors include gender, age, level of education, managerial and work experience, operational skills, training, successful and unsuccessful experiences; Corporate factors contain company age, legal status; size, ownership and managerial characteristics, and finally environmental factors include confusion, heterogeneity, environmental dynamism, customer structure, location, competition and monopoly of the company (Rannikko, 2012). To become a knowledge-based company, a corporation employs university alumni in the first step. In the next step, it shifts its focus to use professionals who work on solving unusual problems. These problems require a combination of convergent, divergent and creative thinking (Massingham, 2008; Jennex \& Durcikova, 2013). In the modern world economy, which is called the knowledge economy, the importance of intangible resources is far greater than tangible resources, because their business requires more time. Therefore, knowledge-based companies need to develop intangible resources for their growth that the most important of which are brand resources (Rosenbaum-Elliott, Percy, \& Pervan, 2015).

\subsection{Theoretical Framework}

In this section, the fundamental theories that could form the bases for designing the initial model of the research probed. The precise study on theories related to the competitive advantage, dynamic capabilities, differentiation, and knowledge-based strategies can support the theoretical framework of the research in order to extract the model with applicable parameters. The operational development of this model in mentioned domain could be beneficial for thriving of knowledge-based companies.

\subsubsection{Competitive Advantages Indicators}

Porter (1990) discusses how to gain advantage or international success in a particular industry. The answer to this question lies in four factors that can turn a business environment into an incentive or deterrent one for companies. The production factors situations, demand conditions, supporting related industries, and finally the strategy, structure and competitiveness of the company are the four factors that separately yet as a one system provide contexts related to the competitiveness of the corporations. The competitive advantage is the unique position of an organization against its rivals that is expanded through the resource development model (Hofer \& Schendel, 1978). Competitive advantage is the companies' ability to attract customers compared to their competitors, relying on organizational capacities and capabilities; and in the end, it is the set of values that a company offers to customers in a way that is higher than customer's costs (Day, 1984). Generally, achieving higher quality requires the use of more expensive components. The main indicators for achieving competitive advantage and their concepts and components have been specified in the following table.

Table I

\subsubsection{Dynamic Capabilities Parameters}

Teece et al. (1997) clarify that dynamic capabilities are processes configured by positions and paths. These processes are the mechanisms and systematic procedures by which the dynamic capabilities are put in use for exploitation (Helfat et al., 2006). These processes consist of co-ordination and integration, learning and reconfiguration. Positions and paths are determinants regarded as the internal and external forces by enabling and activating dynamic capabilities. The enterprise's position will be in a direction based on corporate strategic posture and how competitive advantage could be achieved. For triggering dynamic capabilities, it is needed to review the range of internal and external factors considered as activators of $\mathrm{DC}^{1}$ (Teece et al., 1997).

According to the great number of works to original works on dynamic capabilities such as the original work of Teece et al. (1997), dynamic capabilities were indispensable to face with rapidly variable environments. However, Eisenhardt and Martin (2000) asserted that dynamic capabilities could also be employed in moderate altering conditions. They believed that, in such environments, capabilities 'are detailed, analytic, Sustainable processes with outcomes' which could be predicted whereas in environments with high rate of change, they are simple, very experiential and susceptible processes with unexpected outputs. (Eisenhardt \& Martin, 2000). This caused AragónCorrea and Sharma (2003) to discuss a contingency viewpoint on dynamic capabilities and recognition of

\footnotetext{
${ }^{1}$ Dynamic Capabilities
} 
environmental characteristics and factors such as uncertainty, complexity and munificence which impact the strategic positioning of dynamic capabilities. In acknowledgement of the point that dynamic capabilities are functional in comparatively sustainable environments, some of directed activities at the gradual development or increasing of the value of existing resources could be regarded as dynamic capabilities. According to noticed permanency in the environment of this kind of enterprises, the experience reveals that advertising positively affects the brand that could be predicted. In a similar manner, enterprises that invest in $R \& D$ look forward to result in high-ranked product designs or productive processes from resources advantages.

Figure 1

\subsubsection{Differentiation Dimensions}

Differentiation is a strategic approach to position products advantageously as customers decide which product to choose. A product is differentiated solely because it offers something superior to what is available in competitive products. The success of differentiation varies by market segment as each segment values a particular path of differentiation based on its unique preferences. Differentiation should be managed as vectors, not points. This is the direction that companies are taking in differentiating their products, and are going to stay ahead of competitors by doing it better (McGrath, 1995; McGrath, 2000; Hockema, Blair, \& Goldstone, 2005). The main dimensions of differentiation are as follows.

Figure 2

\subsubsection{Knowledge-based Strategies Parameters}

The new approaches to strategy and organization are the reflections of significant alterations in economics, business and knowledge management. Achieving innovation is crucial for the organization. This not only moderates its performance but also its existence. A set of main elements should be considered in the analysis, designing and using of the strategies based on knowledge. Theses elements include understanding the subject of a knowledge-based organization system and its need for change; focusing on the activities that make the virtual value chain of knowledge-based organization; identifying supporting and opposing forces to change; creating the vision for strategic change; presenting the organizational change message; the creation of the strategic coalition for change; creating a strategic coalition for change; building teams to reach final change; giving information, training and offering consultancy for the participants to change; allocating a remarkable part of time and budget for change by related managers of the knowledge-based company; reflecting this reality by the leaders of change processes, there is no turning back to the previous situation; intensive and close communications between participants for change; the strong involvement and participation of individuals from sectors that are subject to operational change processes; encouraging and supporting the staff creativity; the prudent but effective monitoring of the strategic change processes performance; the specified assessments of progress and results of strategic change; corrections and improvement operations during change; and building sustainable change through knowledge-based strategies (Whitehill, 1997).

Achieving the strategy based on knowledge of the organization is founded primarily on the same approach of logic and methodology as a classic business strategy. Knowledge has the indispensable and decisive role in the strategic knowledge based process to the extent that if a strategy is not developed, the knowledge management needs to conduct an audit of knowledge. It should be noted that it is not possible to achieve the operational strategy of knowledge without redesigning the knowledge management system. The changes which are of realities happen in the content of each phase because of the transition in the foreground of knowledge in many cases such as raw materials, capital input, product and competitive advantage (Muthusamy \& Palanisamy, 2004).

According to Leonard-Barton (1995), throughout the strategic knowledge process, it is demanded to pay more attention to a set of five elements in association with the issue of knowledge-based company and strategies. These factors have been illustrated below.

Figure 3

\section{Research Methodology}

\subsection{Research Process}

According to the main topic and purposes of the research, the induction approach has been employed to conduct the probe. All important data has been initially collected through qualitative research tools, and then after analyzing the data, a model has been designed and a theory has been developed. Afterwards, the research hypotheses have been made based on the relationships among the variables of the research model. In this study, the main framework of the research has been created through concepts derived from knowledge-based companies through both a series of in- 
depth interview data, and an accurate study on literature about competitive advantage, dynamic capabilities, competencies, knowledge, knowledge management, knowledge-based strategies, and differentiation and so on. Meticulous studying preceding researches on inquiry topic causes a better perception to be provided about the research concepts. This process feeds and advances the research as a better inductive research.

\subsection{Population Profile Data and Sampling Method}

The sampling method of this research is nonprobability and non-random with a purpose in mind involves a sample of persons with the demonstrable experience and expertise in the research issue, consisting of knowledge, knowledgecentricity, knowledge-based products (services) and knowledge-based companies and related issue (expert sampling). It has been carried out in 30 active knowledge-based companies in the field of electronics and informatics which have settled in the science and technology park of 6 top universities of Iran. At first, 78 knowledge-based companies are identified as target sample of the research and are preliminary evaluated. After initial evaluation and contact with these companies, fifty four of them show willing to cooperate. Finally, five companies are selected from each university and totally 30 senior managers are deeply interviewed twice within eight months. During this period of time, more than forty hours of the interviewee's voice are recorded and four hundred pages of documentation are collected. The studied companies' field of activities, the university associated with each of them and the number of open codes extracted from the deep interview of each interviewee has been presented in the table II.

Table II

\subsection{Research Methods}

This inquiry is based on an interpretive paradigm and a postpositive philosophy. The research has been established upon an applied and a developmental orientation. It has started with an inductive approach. The qualitative methods have been used in the first part of the probe to build a model and the quantitative methods have been employed to denote the statistics, test the model and present its goodness of fit. This study is primarily initiated with exploratory purpose through grounded theory strategy; then, it is continued with explanatory and descriptive purposes with survey and correlational research strategies.

In qualitative part, applying the grounded theory, the researchers are able to seek and extract the concepts from the obtained data through deep interviews with senior managers of studied knowledge-based companies and conceptualize the latent patterns and structures. In the first stage of GT, after several rounds of punctilious review of obtained data, 308 open codes are extracted. In the next step, these open codes 83 axial codes come from sorting and categorization of the research open codes. Through a detailed study on the research literature, eight new codes are added to the previous axial codes, and the total axial codes of the research increases to 91 codes. In the third step of coding, with high precision and review of codes, the axial codes are grouped into 12 selective codes as the main variables of the research.

In the paper, the axial codes and selective codes are respectively shown in ' $\mathrm{B}$ ' and ' $\mathrm{C}$ '. These codes and their categorization have been represented in the following table.

\section{Table III}

In above table, 78 axial codes are observed in both in-depth interviews with experts and research literature. 8 axial codes have been extracted solely from the theoretical contents and the literature; and 5 axial ones have been derived from the interviews.

Table IV

\subsection{Research Model}

After studying the subject background in foreign and local literature, four generalized and open questions have been regarded as the main questions of the research. The initial conceptual model of the research has been designed considering twelve macro categories and the contextual model. These twelve macro categories have been supposed as main constructs (latent variables) of the study. Value Creation based on Resource Orientation (RO), Dynamic Capabilities (DC) and Competences (CO) form causal conditions. The core phenomenon of the research is Knowledge-centricity (KC). Three variables of Environmental Cognition (EC), Knowledge Approaches (KA) and Knowledge Management (KM) constitute contextual conditions. Intervening conditions include Branding and Brand Management (BR), and Strategic Agility (SA). Differentiation Strategies (DS) and Knowledge-based Strategies (KS) are regarded as the main strategies of the research model; and consequently, it is expected that the knowledge-based companies gain competitive advantage through this model.

Figure 4 


\subsection{Research Hypotheses}

In this paper, we start the probe with this question that how a knowledge-based company is able to attain competitive advantage. Which tools, elements, factors, strategies and features are required that actively and competitively involve a knowledge-based company in markets to achieve the summit? To answer this multidimensional technical question, the qualitative part of the research is conducted and the initial model is designed based on the qualitative research findings. For testing the model which includes seventeen causal relations, the research hypotheses are formed. These hypotheses are as the following.

\section{Table V}

The initial extracted model of the research from the combination of GT method obtained codes and research literature in-depth study acquired codes is formed as follows, consisting of 12 constructs and 91 primary indicators.

Figure 5

\subsection{Data Collection}

In the quantitative part of the research, survey and correlation strategies are the main research strategies used in direction of testing the built model in qualitative part. Considering the research subject and under the studied variables, the required information to test the hypotheses is collected through a questionnaire with interview. The target audiences of the questionnaire are the senior managers of the same 30 knowledge-based companies who have been interviewed in qualitative section of the probe. The final version of the questionnaire contains 114 questions. The questionnaire is divided into 3 types of questions. The first part includes context and demographic questions. The second part is a set of questions related to the components of 12 variables; and the last part is used to evaluate the main constructs of the research as total evaluators.

\subsection{Research Measures}

In this article, twelve main constructs are evaluated through structured survey. Indicators are the defining factors of each construct as any change in the components of a construct can affect the related variable. Removing any of the indicators may alter the concept of the respective construct and disrupt the overall structure of the model. The structural equation modeling and the covariance structure are used for better analysis of the obtained model of this research. In the present study, the researchers have applied path analysis to estimate and interpret the relationship of variables in the model. These relationships can be correctly interpreted through estimating the values. In fact, the estimated values represent the significance of the relationships. In structural equation modeling, estimation means the measurement of relationships intensity, and evaluation signifies that how much of fitness there is between the data collected by the researchers and their developed model adapted from the theoretical frameworks. In this research, the partial least squares (PLS) approach has been used to evaluate, estimate and interpret the relationships in the model.

\section{Data Analysis and Findings}

\subsection{The Technical Properties of Measuring Tools}

The credibility of each research depends on credibility of data collection tools of that research. The researchers have evaluated the technical properties of the tools especially questionnaires with interviews used in this study to ensure the accuracy of the obtained results.

\subsubsection{Credibility of the research in PLS}

The value of Loadings is obtained through calculating the correlation of the indicators of a construct with that construct. If this value is equal to or higher than 0.4 , it points out that the variance between a construct and its indicators is greater than the variance of measurement error and, therefore the reliability is acceptable for that measurement part of the model. Of course, some authors such as Rivard \& Huff (1988) recommended the measure of 0.5 as the criterion for loadings.

The PLS has been used for initial evaluation of loadings of the measurement parts of the research model. In the beginning, after software calculation, the acquired loading value of 13 indicators is less than 0.5 and the rest are above the benchmark value. By removing indicators with low loading values from related constructs, loadings of residual indicators in the modified model are evaluated by the software again and finally, the loading values of 78 remaining indicators in the model are above 0.5 which represents acceptable reliability for all measurement parts of the model. The loadings of all indicators have been given in the table below.

\section{Table VI}


In Table VI, the indicators of each construct (B) have been ranked based on the intensity of effect on the connected construct $(\mathrm{C})$ in order to identify the most influential indicators of the model.

\section{Table VII}

\subsubsection{Formative Models Evaluation by Significance of Loadings and Collinearity Criteria}

Hair et al. (2011) introduce two criteria of T-Value for evaluation of indicators loading significance, and VIF for evaluation of indicators collinearity. If the T-Value of one construct's indicators with formative model is less than 1.96, the researchers are allowed to remove those indicators from the model in confidence level of $95 \%$. This should be done by studying the research theoretical framework, regarding to the viewpoint of experts, and checking the results of content validity of the research. Deletion of the indicators is allowed only when this work does not impair in mentioned item. T-Value of all indicators of the model has been listed in Table VIII.

All T-Values of all residual indicators are greater than 1.96; therefore, there is no need to remove an indicator again.

If there is a high collinearity among the indicators of one formative part of the research model, the model total goodness of fit comes into question. The collinearity of indicators is evaluated through computation of a criterion called Variance Inflation Factor (VIF) for each of them. If the value of this criterion for an indicator is equal to or greater than 5, it implies that at least $80 \%$ of the scale that an indicator defines the related construct is explained by other indicators, and thus there is no need for that indicator to remain in the research model (Cassel, Hackl, \& Westlund, 1999; Diamantopoulos \& Winklhofer, 2001; Grewal, Cote, \& Baumgartner, 2004). How to calculate VIF for each indicator is as follows:

$V I F(B)=\frac{1}{1-R^{2}(B)}$

The value of $\mathrm{R}$ for each indicator is equal to the second power of its loading. The values of $\mathrm{R}^{2}$ and VIF of all indicators of the model have been listed in Table VII. As can be seen, the VIF value of all indicators of the model is less than 5, revealing that the collinearity among the residual indicators of model constructs is acceptable.

Table VIII

\subsubsection{Convergent Validity and Quality Evaluation by Communality Criterion}

The quality of measurement parts of the model in PLS method is evaluated by communality criterion. It demonstrates how much of the indicators' variability is explained by their associated construct. The communality values of all model indicators have been computed by PLS and given in the following table. The mean of communality values of each construct's indicators makes that construct's communality up which is also called Average Variance Extracted (AVE). If these values are above 0.5 , it confirms acceptable convergent validity for the model measurement parts. The communality value of each construct has been pointed out in the Table VIII.

Table IX

\subsubsection{Path Analysis for Variables Causal Relationship}

Another important issue in fitting the final model of the research indispensable to be assessed is the efficacy and the significance of the causal relationship between the research variables. The criterion for measuring the causal relationship between constructs in the structural part of the model is the T-Value, and the criterion of efficacy is the standardized beta coefficient $(\beta)$ or the path coefficient. If the T-Value of path between two constructs is greater than 1.96, it represents a relationship between constructs and thus confirms the hypothesis that one construct (variable) affects another construct (variable) in a $95 \%$ confidence interval.

The standardized beta coefficient $(\beta)$ exposes that how much change it takes in dependent variable (effect) for one unit change in independent variable (cause). In accordance with Table IX, all T-Values for the paths between two constructs are more than 1.96 and hence, all the relationships in the research model are significant and the hypotheses related to the causal relationships are accepted. The values of standardized beta coefficient $(\beta)$ for the model paths show that in 15 paths, the efficacy is high; in path 11 (C10 - C11), it is average; and in path 14 (C6 - C4), it is low.

Table X

\subsubsection{Structural Part Evaluation by Redundancy criteria and $R^{2}$ as a Connector}

$\mathrm{R}^{2}$ is a criterion used to connect the measurement and structural part in structural equation modeling and show the effect that an exogenous variable has on an endogenous one. The $\mathrm{R}^{2}$ value is calculated by PLS only for endogenous (dependent) constructs of the model and its value is zero for exogenous constructs. Hulland (1999) accentuated that in the studies use the PLS method, the R square should be reported for all endogenous variables of the research. The 
greater the $\mathrm{R}^{2}$ value of the endogenous constructs, the better the fitting of a model. Chin (1998) introduced three values of $0.19,0.33$ and 0.67 as a standard for weakness, moderation and strength of the $\mathrm{R}$ square in structural part of a model. As presented in Table XI, the $\mathrm{R}^{2}$ value of three endogenous variables of C4, C11 and C12 extracted by PLS software are strong, indicating the high impressionability of these endogenous (dependent) variables from related exogenous variables. The $\mathrm{R}$ square value of $\mathrm{C} 1$ as the final dependent and exogenous variable of the model is 0.577 , revealing relative strong impressionability of the main dependent from $\mathrm{C} 4$ and $\mathrm{C} 11$.

The main criterion for fitting the structural part of the research obtained from the multiplication of every endogenous construct's communality by its related $\mathrm{R}^{2}$ is called Redundancy (Red). This criterion shows variability amount of an endogenous construct's indicators influenced by one or more exogenous structures. The Redundancy value for each of the endogenous constructs of the research has been calculated using the formula given below.

$$
\begin{aligned}
& \operatorname{Red}_{C 12}=\text { Communalit }_{C 12} \times R_{C 12}^{2}=0.713 \times 0.678=0.483 \\
& \operatorname{Red}_{C 4}=\text { Communality }_{C 4} \times R_{C 4}^{2}=0.650 \times 0.880=0.572 \\
& \text { Red }_{C 11}=\text { Communality }_{C 11} \times R_{C 11}^{2}=0.733 \times 0.704=0.516 \\
& \text { Red }_{C 1}=\text { Communality }_{C 12} \times R_{C 1}^{2}=0.673 \times 0.577=0.388
\end{aligned}
$$

After calculating the values of Red and $\mathrm{R}^{2}$ criteria for endogenous variables of the model, these values are presented in Table XI.

\section{Table XI}

An essential criterion for measuring the structural part fitting of the structural equation models is the average amount of redundancies related to the endogenous variables of the model. This new criterion is represented with $\overline{R e d}$. The greater the value of $\overline{R e d}$, the better fit the structural part of the research model.

$\overline{\operatorname{Red}}=\frac{\operatorname{Red}(C 1)+\operatorname{Red}(C 4)+\operatorname{Red}(C 11)+\operatorname{Red}(C 12)}{4}=0.491$

The following model is the final Structural Equations based model of the research that includes all the studied variables and their indicators. The indicators of each variable are considered after elimination of factors containing weak loading values, indispensable calculations in path analysis and fitting of the measuring parts of the model by PLS software. In the final model, considering the calculations of measuring and structural parts fitting criterion, the path coefficients have been denoted on paths.

\section{Figure 6}

\subsubsection{The Full Model Fitting Evaluation by Goodness of Fit (GoF) Criterion}

The GoF criterion is related to the total part of structural equation models. It means that the researchers can control the fitting of the overall part. This criterion has been masterminded by Tenenhaus et al. (2004) and is calculated according to the following formula. In this formula, $\overline{\text { Comunalities }}$ is the mean of the communality values of the research constructs and $\overline{R^{2}}$ is the mean of $\mathrm{R}$ square values of endogenous constructs of the model. The values of

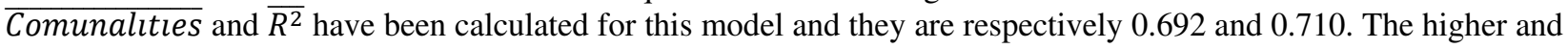
the closer to one these values are, the more they have a role in goodness of fit for the research model.

$$
\begin{aligned}
& \overline{\text { Comunalities }}=\frac{0.678+0.703+0.714+0.650+0.664+0.685+0.687+0.680+0.728+0.674+0.733+0.713}{12}=\frac{8.309}{12}=0.692 \\
& \overline{R^{2}}=\frac{R^{2}(C 1)+R^{2}(C 4)+R^{2}(C 11)+R^{2}(C 12)}{4}=0.710
\end{aligned}
$$

Wetzels et al. (2009) have determined three values of $0.01,0.25$ and 0.36 as weak, moderate and strong ones for GoF.

GoF $=\sqrt[2]{\overline{\text { Communalitles }} \times \overline{R^{2}}}=\sqrt[2]{0.692 \times 0.710}=0.701$

Achieving the value of 0.710 for GoF shows that a strong fitting has been done for the research model.

\section{Results and Discussion}

In developed countries, many successful corporations are about to gain competitive advantage through the knowledge-based capabilities since the production, distribution and utilization of knowledge are conceived as the keys to develop, growth and wealth creation in most fields for them. The existence of these companies leads to the 
emergence of the dynamic type of economy called the knowledge-based economy. This type of economy is made up of a vast network of knowledge-based companies that attempt to make a knowledge-based business in order to covert knowledge into wealth. These companies' economic activities are based on and associated with research and development operations in the field of new and developed technologies. These activities include all functions that commercialize their R\&D outcomes such as design, production, supplying goods or applications, technology generation and delivery, utilization of advanced technologies with added value, consultancy, and presentation of technical and knowledge-based services. This probe has been carried out on 30 knowledge-based companies active in the fields of electronics and informatics. The results of an in-depth interview with their experts and a precise study on research literature, theoretical frameworks and concepts which has led to a comprehensive model show that achieving knowledge-centricity main phenomenon through dynamic capabilities requires presence of value creation on the basis of resource orientation together with competences. In accordance with final model of the research, the knowledge-based companies can attain a meaningful success and reach the summit and sustainable success in the knowledge-centricity main phenomenon when they pay particular attention to two kinds of specialized strategies in parallel. The first one is the path related to the differentiation strategies and the second is the path of knowledgebased strategies. Along with these two paths of strategies, contextual factors such as environmental cognition, knowledge management and knowledge approaches have a positive and significant effect on both strategies. The efficacy of these factors on the differentiation strategies is higher than on knowledge-based strategies. The intervening conditions that affect both strategies are the branding and brand management, and also strategic agility for these knowledge-based companies. Branding and brand management have the most profound effect on differentiation strategies whereas strategic agility has the most intensive effect on knowledge-based strategies. As a conclusion, the most influential indicators related to model variables in order to gain competitive advantage are as follows.

(1) In resource orientation (RO), dynamic capabilities (DC), and competencies (CO), they respectively are human capital resources (B13), intangible assets (B16), and monetary and financial resources (B11); the improvement of organizational efficiency (B62), the absorbing capabilities (B56), and external position of the organization (B59); essential competences based on internal conformity, stability and comprehensiveness (B73), integrative competencies (B70), and Organizational Competencies (B68). (2) In core phenomenon of knowledge-centricity $(\mathrm{KC})$, they are spin-off knowledge-centricity (B90), knowledge-centricity emphasizing on R\&D and economic activities along with R\&D activities (B88), and knowledge-centricity with high-tech and new technology (B91). (3) In core strategies that is to say differentiation strategies (DS), and knowledge-based strategies (KS), they respectively are differentiation in accountability to customer (B26), differentiate in offering of complementary services (B23), and differentiation in offering of hybrid and discrete products or services (B18); dynamics in goals (B84), the scope of knowledge thinking (B86), and the nature of the knowledge vision (B87). (4) In contextual conditions of environmental cognition (EC), knowledge approaches (KA), and knowledge management (KM), They respectively are providing the requirements of a changing environment by identifying and adapting to environmental change (B9), and environmental status analysis (B10); the approaches based on the nature of knowledge work (B74), the approaches based on the knowledge attitude (B75); the knowledge policy and strategy (B81), the knowledge communications (B79), and tendency to the knowledge development, transfer and support (B77). (5) In intervening conditions of environmental cognition branding and brand management (BR), and strategic agility (SA), they respectively are brand equity (B35), brand identity (B33), and brand commitment and persistence (B37); selection of the strategic knowledge goals (B41), Being Proactive (B46), and the change in the approach of making money from created value (B51). (6) In final consequence of the research means competitive advantage (CA), they are product innovation, innovative capabilities and the ability to create knowledge (B3), situational advantage (B6), and cost leadership (B2).

Compared to other studies, it seems that the present study has more scrutiny, accuracy, depth and comprehensiveness and uses more influential and impressionable variables that can be used as an operational pattern for knowledgebased companies. The research has been conducted in the active knowledge-based companies in the field of electronics and informatics. What is suggested is that the other researchers can conduct similar studies in other knowledge-based fields.

\section{References}

Agrawala, J., \& Kamakura, W. A. (1999). Country of origin: A competitive advantage? International Journal of Research in Marketing, 16(4), 255-267. doi: 10.1016/S0167-8116(99)00017-8

Ambe, I. M. (2010). Agile supply chain: strategy for competitive advantage. Journal of Global Strategic Management, 4(1). doi: 10.20460/JGSM.2010415835 
Ambrosini, V., \& Bowman, C. (2009). What are dynamic capabilities and are they a useful construct in strategic management? International journal of management reviews, 11(1), 29-49.

Anderson, J. C., Narus, J. A., \& Van Rossum, W. (2006). Customer value propositions in business markets. Harvard Business Review, 84(3), 90.

Aragón-Correa, J. A., \& Sharma, S. (2003). A Contingent Resource-Based View of Proactive Corporate Environmental Strategy. Academy of Management Review, 28(1), 71-88. doi: 10.5465/AMR.2003.8925233

Badawy, A. M. (2008). Fast Strategy: How Strategic Agility Will Help You Stay Ahead of the Game. Journal of Engineering and Technology Management, 26(4), 342-344. doi: 10.1016/j.jengtecman.2009.10.007

Banker, R. D., Mashruwala, R., \& Tripathy, A. (2014). Does a differentiation strategy lead to more sustainable financial performance than a cost leadership strategy? Management Decision.

Barney, J. B. (1991). Firm Resources and Sustained Competitive Advantage. Journal of Management, 17(1), 99-120. doi: 10.1177/014920639101700108

Barney, J. B. (1995). Looking inside for competitive advantage. Academy of Management Perspectives, 9(4), 49-61.

Barney, J. B., \& Hesterly, W. S. (2014). Strategic Management and Competitive Advantage: Concepts and Cases (5th ed.). United Kingdom: Pearson.

Barrales-Molina, V., Benitez-Amado, J., \& Perez-Arostegui, M. N. (2010). Managerial perceptions of the competitive environment and dynamic capabilities generation. Industrial management \& data systems.

Barrena, R., \& Sánchez, M. (2009). Using emotional benefits as a differentiation strategy in saturated markets. Psychology \& Marketing, 26(11), 1002-1030.

Berger, J., \& Heath, C. (2007). Where consumers diverge from others: Identity signaling and product domains. Journal of Consumer Research, 34(2), 121-134.

Berger, J. A., Heath, C., \& Ho, B. (2005). Divergence in cultural practices: Tastes as signals of identity.

Bhattacharya, C. B., \& Sen, S. (2003). Consumer-company identification: A framework for understanding consumers' relationships with companies. Journal of marketing, 67(2), 76-88.

Bogodistov, Y., Presse, A., Krupskyi, O. P., \& Sardak, S. (2017). Gendering dynamic capabilities in micro firms. Revista de Administração de Empresas, 57(3), 273-282.

Bose, R. (2008). Competitive intelligence process and tools for intelligence analysis. Industrial management \& data systems, 108(4), 510-528. doi: https://doi.org/10.1108/02635570810868362

Cabral, J. E. D. O. (2010). Firms' Dynamic Capabilities, Innovative Types and Sustainability: A Theoretical Framework. Paper presented at the XVI International Conference on Industrial Engineering and Operations Management (ICIEOM).

Camisón, C. (2004). Shared, competitive, and comparative advantages: a competence-based view of industrialdistrict competitiveness. Environment and planning A, 36(12), 2227-2256.

Cassel, C., Hackl, P., \& Westlund, A. H. (1999). Robustness of partial least-squares method for estimating latent variable quality structures. Journal of applied statistics, 26(4), 435-446.

Cheng, J.-H., Chen, M.-C., \& Huang, C.-M. (2014). Assessing inter-organizational innovation performance through relational governance and dynamic capabilities in supply chains. Supply Chain Management: An International Journal, 19(2), 173-186. doi: https://doi.org/10.1108/SCM-05-2013-0162

Chin, W. W. (1998). The partial least squares approach to structural equation modeling. Modern methods for business research, 295(2), 295-336.

Choo, C. W., \& Bontis, N. (2002). The Strategic Management of Intellectual Capital and Organizational Knowledge: Oxford University Press.

Christensen, H. K. (2010). Defining customer value as the driver of competitive advantage. Strategy \& Leadership, 38(5), 20-25. doi: https://doi.org/10.1108/10878571011072048

Clulow, V., Gerstman, J., \& Barry, C. (2003). The resource-based view and sustainable competitive advantage: the case of a financial services firm. Journal of European Industrial Training.

Das, S. R., \& Joshi, M. P. (2007). Process innovativeness in technology services organizations: Roles of differentiation strategy, operational autonomy and risk-taking propensity. Journal of Operations Management, 25(3), 643-660.

Davcik, N. S., \& Sharma, P. (2016). Marketing resources, performance, and competitive advantage: A review and future research directions. Journal of Business Research, 69(12), 5547-5552.

Davenport, T. H., De Long, D. W., \& Beers, M. C. (1998). Successful knowledge management projects. Sloan management review, 39(2), 43-57.

Davenport, T. H., \& Prusak, L. (1998). Working Knowledge: How Organizations Manage what They Know: Harvard Business Press.

Day, G. S. (1984). Strategic market planning: The pursuit of competitive advantage: West Group. 
Diamantopoulos, A., \& Winklhofer, H. M. (2001). Index construction with formative indicators: An alternative to scale development. Journal of marketing research, 38(2), 269-277.

Distanont, A., \& Khongmalai, O. (2018). The role of innovation in creating a competitive advantage. Kasetsart Journal of Social Sciences.

Duncan, T. (2008). Integrated Marketing Communications (European ed.): McGraw-Hill.

Easterby-Smith, M., Graça, M., Antonacopoulou, E., \& Ferdinand, J. (2008). Absorptive Capacity: A Process Perspective. Management learning, 39(5), 483-501.

Eckert, P., Goldman, S., \& Wenger, E. (1997). The School as a Community of Engaged Learners. Wingspread Journal, 9(3).

Eisenhardt, K. M., \& Martin, J. A. (2000). Dynamic capabilities: what are they? Strategic Management Journal, 21(10-11), 1105-1121. doi: 10.1002/1097-0266(200010/11)

Ellonen, H.-K., Jantunen, A., \& Kuivalainen, O. (2011). The role of dynamic capabilities in developing innovationrelated capabilities. International Journal of Innovation Management, 15(03), 459-478.

Eriksson, T. (2014). Processes, antecedents and outcomes of dynamic capabilities. Scandinavian Journal of Management, 30(1), 65-82.

Esper, T. L., Fugate, B. S., \& Davis-Sramek, B. (2007). Logistics learning capability: sustaining the competitive advantage gained through logistics leverage. Journal of Business Logistics, 28(2), 57-82.

Etzkowitz, H. (2006). The entrepreneurial university and the triple helix as a development paradigm. Paper presented at the Ethiopia Triple Helix Conference, Addis Ababa

Evans, N. G. (2016). Sustainable competitive advantage in tourism organizations: A strategic model applying service dominant logic and tourism's defining characteristics. Tourism Management Perspectives, 18, 14-25.

Garvin, D. A. (1983). Spin-offs and the new firm formation process. California management review, 25(2), 3-20.

Ghemawat, P. (1986). Sustainable advantage. Harvard Business Review, 64(5), 53-58.

Grant, R. M., \& Baden-Fuller, C. (2004). A knowledge accessing theory of strategic alliances. Journal of management studies, 4l(1), 61-84.

Grewal, R., Cote, J. A., \& Baumgartner, H. (2004). Multicollinearity and measurement error in structural equation models: Implications for theory testing. Marketing science, 23(4), 519-529.

Griffith, D. A., Noble, S. M., \& Chen, Q. (2006). The performance implications of entrepreneurial proclivity: A dynamic capabilties approach. Journal of Retailing, 82(1), 51-62.

Hair, J. F., Ringle, C. M., \& Sarstedt, M. (2011). PLS-SEM: Indeed a silver bullet. Journal of Marketing theory and Practice, 19(2), 139-152.

Helfat, C. E., Finkelstein, S., Mitchell, W., Peteraf, M., Singh, H., Teece, D., \& G., W. S. (2006). Dynamic Capabilities: Understanding Strategic Change in Organizations. London: Wiley-Blackwell.

Helfat, C. E., Finkelstein, S., Mitchell, W., Peteraf, M., Singh, H., Teece, D., \& Winter, S. G. (2009). Dynamic capabilities: Understanding strategic change in organizations: John Wiley \& Sons.

Helfat, C. E., \& Peteraf, M. A. (2009). Understanding dynamic capabilities: progress along a developmental path: Sage publications Sage UK: London, England.

Hill, C. W. L., \& Jones, G. R. (2007). Strategic Management: An Integrated Approach (8 ed.): Cengage Learning.

Hoang, D. T., Igel, B., \& Laosirihongthong, T. (2006). The impact of total quality management on innovation: Findings from a developing country. International journal of quality \& reliability management, 23(9), 10921117. doi: https://doi.org/10.1108/02656710610704230

Hofer, C. W., \& Schendel, D. (1978). Strategy Formulation: Analytical Concepts, St. Paul. MN. West.

Horney, N., Pasmore, B., \& O'Shea, T. (2010). Leadership Agility: A business Imperative for a VUCA World. People and Strategy, 33(4), 33-38.

Hulland, J. (1999). Use of partial least squares (PLS) in strategic management research: A review of four recent studies. Strategic management journal, 20(2), 195-204.

Jantunen, A., Ellonen, H.-K., \& Johansson, A. (2012). Beyond appearances-do dynamic capabilities of innovative firms actually differ? European management journal, 30(2), 141-155.

Jassim, R. (2001). Competitive advantage through the employees: A practical guide. Paper presented at the Arab Second Conference in Management, Cairo Egypt.

Jennex, M. E., \& Durcikova, A. (2013). Assessing knowledge loss risk. Paper presented at the 2013 46th Hawaii International Conference on System Sciences.

Jennings, P., \& Beaver, G. (1997). The performance and competitive advantage of small firms: a management perspective. International small business journal, 15(2), 63-75.

Kahaner, L. (1997). Competitive intelligence: how to gather analyze and use information to move your business to the top (First ed.): Simon and Schuster. 
Kak, A., \& Sushil, H. (2002). Sustainable competitive advantage with core competence: a review. Global Journal of flexible systems management, 3(4), 23-38.

Kaleka, A. (2002). Resources and capabilities driving competitive advantage in export markets: guidelines for industrial exporters. Industrial Marketing Management, 31(3), 273-283.

Keizer, J. A., Dijkstra, L., \& Halman, J. I. (2002). Explaining innovative efforts of SMEs.: An exploratory survey among SMEs in the mechanical and electrical engineering sector in The Netherlands. Technovation, 22(1), 113.

Klepper, S., \& Sleeper, S. (2005). Entry by spinoffs. Management science, 51(8), 1291-1306.

Ko, H.-T., \& Lu, H.-P. (2010). Measuring innovation competencies for integrated services in the communications industry. Journal of service Management, 21(2), 162-190.

Kosonen, M., \& Dotz, Y. (2007). Fast Strategy: how Strategic Agility will help you stay ahead of the game: Pearson Education UK.

Kumar, P., Dass, M., \& Kumar, S. (2015). From competitive advantage to nodal advantage: Ecosystem structure and the new five forces that affect prosperity. Business Horizons, 58(4), 469-481.

Lawler III, E. E. (1994). From job-based to competency-based organizations. Journal of organizational behavior, 15(1), 3-15. doi: https://doi.org/10.1002/job.4030150103

Lee, P.-Y., Chen, H.-H., \& Shyr, Y.-H. (2011). Driving dynamic knowledge articulation and dynamic capabilities development of service alliance firms. The Service Industries Journal, 31(13), 2223-2242.

Leonard-Barton, D. (1995). Wellsprings of knowledge: building and sustaining the sources of innovation (3 ed.): Harvard Business School Press.

Lockwood, N. R. (2007). Leveraging employee engagement for competitive advantage. Society for Human Resource Management Research Quarterly, 1(1), 1-12.

Lorenzo, J. R. F., Rubio, M. T. M., \& Garcés, S. A. (2018). The competitive advantage in business, capabilities and strategy. What general performance factors are found in the Spanish wine industry? Wine Economics and Policy, 7(2), 94-108.

Ma, H. (1999). Anatomy of competitive advantage: a SELECT framework. Management Decision, 37(9), 709-718.

Mahdi, O. R., \& Almsafir, M. K. (2014). The role of strategic leadership in building sustainable competitive advantage in the academic environment. Procedia-Social and Behavioral Sciences, 129, 289-296.

Massingham, P. (2008). Measuring the impact of knowledge loss: more than ripples on a pond? Management learning, 39(5), 541-560.

Masteika, I., \& Čepinskis, J. (2015). Dynamic capabilities in supply chain management. Procedia-Social and Behavioral Sciences, 213, 830-835.

Matthyssens, P., \& Vandenbempt, K. (1998). Creating competitive advantage in industrial services. Journal of Business \& Industrial Marketing.

McGrath, M. E. (1995). Product strategy for high-technology companies: how to achieve growth, competitive advantage, and increased profits: Irwin Professional Pub.

McGrath, M. E. (2000). Product strategy for high technology companies: McGraw-Hill companies.

Miller, A., Gartner, W. B., \& Wilson, R. (1989). Entry order, market share, and competitive advantage: A study of their relationships in new corporate ventures. Journal of Business Venturing, 4(3), 197-209.

Morgan, N. A., Vorhies, D. W., \& Mason, C. H. (2009). Market orientation, marketing capabilities, and firm performance. Strategic management journal, 30(8), 909-920.

Moss, E., Rousseau, D., Parent, S., St-Laurent, D., \& Saintonge, J. (1998). Correlates of attachment at school age: Maternal reported stress, mother-child interaction, and behavior problems. Child development, 69(5), 13901405.

Muthusamy, S. K., \& Palanisamy, R. (2004). Leveraging cognition for competitive advantage: a knowledge-based strategy process. Journal of information \& Knowledge management, 3(03), 259-272.

Newton, S. K., Gilinsky Jr, A., \& Jordan, D. (2015). Differentiation strategies and winery financial performance: An empirical investigation. Wine Economics and Policy, 4(2), 88-97.

Nicolescu, O. (2006). Knowledge Based Strategy. Paper presented at the Zagreb International Review of Economics $\&$ Business, Economics Faculty, Zagreb. Original Scientific Paper retrieved from

Nicolescu, O. (2011). The Specific of Knowledge-based Strategies. Review of General Management, 14(2).

Nicolescu, O., \& Verboncu, I. (2007). Fundamentele managementului organizației: Tribuna Economică.

Nonaka, I., \& Takeuchi, H. (1995). The knowledge-creating company: How Japanese companies create the dynamics of innovation: Oxford university press.

Nonaka, I., Von Krogh, G., \& Voelpel, S. (2006). Organizational knowledge creation theory: Evolutionary paths and future advances. Organization studies, 27(8), 1179-1208. 
O'Reilly III, C. A., \& Tushman, M. L. (2008). Ambidexterity as a dynamic capability: Resolving the innovator's dilemma. Research in organizational behavior, 28, 185-206.

Parasuraman, A. (1997). Reflections on gaining competitive advantage through customer value. Journal of the academy of marketing science, 25(2), 154.

Paun, D. (1993). When to bundle or unbundle products. Industrial Marketing Management, 22(1), 29-34.

Pavlou, P. A., \& El Sawy, O. A. (2011). Understanding the elusive black box of dynamic capabilities. Decision Sciences, 42(1), 239-273.

Pereira, C. R., Silva, A. L. D., \& Tate, W. L. (2015). The Role of Purchasing and Supply Management (PSM) in Supply Chain Resilience. Paper presented at the XXXIX Encontro da ANPAD - EnANPAD 2015.

Phillips, L. W., Chang, D. R., \& Buzzell, R. D. (1983). Product quality, cost position and business performance: a test of some key hypotheses. Journal of marketing, 47(2), 26-43.

Porter, M. E. (1988). Competitive Advantage - Creating and Sustaining Superior Performance (1 Edition ed.): Free Press.

Porter, M. E. (1990). New Global Strategies for Competitive Advantage. [General review]. Strategy \& Leadership, 18(3), 4-14. doi: 10.1108/eb054287

Pundziene, A., \& Teece, D. J. (2016). New applications of dynamic capability research. Baltic Journal of Management, 11(3). doi: https://doi.org/10.1108/BJM-05-2016-0103

Rannikko, H. (2012). Early Development of New Technology-Based Firms: A Longitudinal Aanalysis on New Technology-Based Firms' Development from Population Level and Firm Level Perspectives.

Rodenbach, M., \& Brettel, M. (2012). CEO experience as micro-level origin of dynamic capabilities. Management Decision, 50(4), 611-634. doi: https://doi.org/10.1108/00251741211220174

Rong, H., Hongshan, X., \& Jiang, Y. (2013). Complex dynamics for airlines' price competition with differentiation strategy. Journal of Transportation Systems Engineering and Information Technology, 13(1), 11-16.

Rosenbaum-Elliott, R., Percy, L., \& Pervan, S. (2015). Strategic Brand Management (illustrated ed.): Oxford University Press, USA.

Rouach, D., \& Santi, P. (2001). Competitive intelligence adds value:: Five intelligence attitudes. European management journal, 19(5), 552-559.

Roundy, P. T., \& Fayard, D. (2018). Dynamic capabilities and entrepreneurial ecosystems: the micro-foundations of regional entrepreneurship. The Journal of Entrepreneurship, 28(1), 94-120. doi: https://doi.org/10.1177/0971355718810296

Rzepka, A. (2017). Inter-organizational relations as a one of sources of competitive advantage of contemporary enterprises in the era of globalization. Procedia Engineering, 174, 161-170.

Saeidi, P., Saeidi, S. P., Sofian, S., Saeidi, S. P., Nilashi, M., \& Mardani, A. (2019). The impact of enterprise risk management on competitive advantage by moderating role of information technology. Computer Standards \& Interfaces, 63, 67-82.

Safari Kahreh, M., Ahmadi, H., \& Hashemi, A. (2011). Achieving competitive advantage through empowering employees: An empirical study. Far East Journal of Psychology and Business, 3(2), 26-37.

Salvato, C., \& Vassolo, R. (2018). The sources of dynamism in dynamic capabilities. Strategic management journal, 39(6), 1728-1752.

Sandberg, E., \& Åman, P. (2010). Logistics learning mechanisms and capabilities: towards an understanding of sustainable competitive advantage. Logistics Research, 2(2), 97-108.

Sheehan, N. T., \& Stabell, C. B. (2010). Reputation as a driver in activity level analysis: reputation and competitive advantage in knowledge intensive firms. Corporate Reputation Review, 13(3), 198-208.

Srivastava, R. K., Shervani, T. A., \& Fahey, L. (1998). Market-Based Assets and Shareholder Value: A Framework for Analysis. Journal of marketing, 62(1), 2-18.

Souza, I. M. d. (2012). Gestão das Universidades Federais Brasileiras: uma abordagem fundamentada na gestão do conhecimento.

Svetličič, M., Jaklič, A., \& Burger, A. (2007). Internationalization of small and medium-size enterprises from selected central European economies. Eastern European Economics, 45(4), 36-65.

Teece, D. J. (2007). Explicating dynamic capabilities: the nature and microfoundations of (sustainable) enterprise performance. Strategic Management Journal, 28(13), 1319-1350. doi: 10.1002/smj.640

Teece, D. J. (2018a). Business models and dynamic capabilities. Long Range Planning, 51(1), 40-49.

Teece, D. J. (2018b). Dynamic capabilities as (workable) management systems theory. Journal of Management \& Organization, 24(3), 359-368.

Teece, D. J., Pisano, G., \& Shuen, A. (1997). Dynamic capabilities and strategic management. Strategic management journal, 18(7), 509-533. 
Tenenhaus, M., Amato, S., \& Esposito Vinzi, V. (2004). A global goodness-of-fit index for PLS structural equation modellingProceedings of the XLII SIS scientific meeting (Vol. 1, pp. 739-742).

Ulrich, D., \& Lake, D. (1991). Organizational capability: Creating competitive advantage. Academy of Management Perspectives, 5(1), 77-92. doi: https://doi.org/10.5465/ame.1991.4274728

Venkatesh, S., Berry, L. L., \& Dotzel, T. (2009). A Practical Guide to Combining Products and Services. Harvard Business Review, 87(11), 16-19.

Volberda, H. W., Foss, N. J., \& Lyles, M. A. (2010). Perspective-Absorbing the concept of absorptive capacity: How to realize its potential in the organization field. Organization science, 21(4), 931-951.

Wang, C. L., \& Ahmed, P. K. (2007). Dynamic capabilities: A review and research agenda. International journal of management reviews, 9(1), 31-51.

Wang, C. L., \& Ahmed, P. K. (2003). Structure and structural dimensions for knowledge-based organizations. Measuring Business Excellence.

Wang, M., \& Li, R. (2013). The study on the dimensions of dynamic capability of enterprises. Paper presented at the 2013 International Conference on Advanced ICT and Education (ICAICTE-13).

Wetzels, M., Odekerken-Schröder, G., \& Van Oppen, C. (2009). Using PLS Path Modeling for Assessing Hierarchical Construct Models: Guidelines and Empirical Illustration. Management Information Systems Research Center, 33(1), 177-195.

Wiklund, J., \& Shepherd, D. (2003). Knowledge-based resources, entrepreneurial orientation, and the performance of small and medium-sized businesses. Strategic management journal, 24(13), 1307-1314.

Woodruff, R. B. (1997). Customer value: the next source for competitive advantage. Journal of the academy of marketing science, 25(2), 139.

Ya-Hui, H., \& Chia-Hsiu, C. (2015). Clustering of Tea Processing Industry Based on GIS Analysis. International Journal of Agricultural Sciences and Natural Resources, 2(3), 58-66.

Zhang, M. J. (2007). Is support for top managers' dynamic capabilities, environmental dynamism, and firm performance: an empirical investigation. 


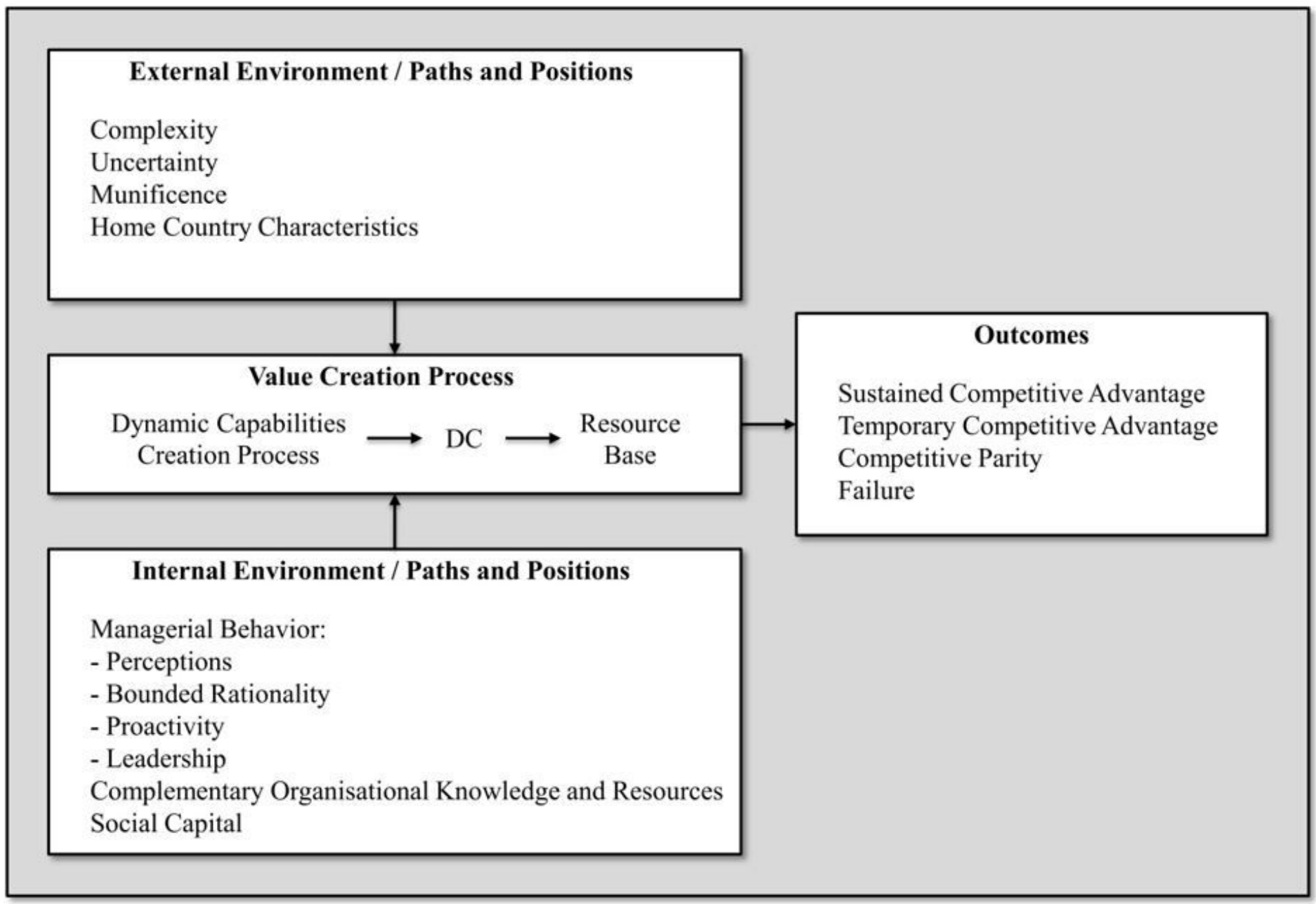

\section{Figure 1}

Activating Factors of Dynamic Capabilities (Ambrosini \& Bowman, 2009) 


\section{The Main Dimensions of Differentiation}

- Differentiation using Unique Features

- Differentiation by Measurable Customer Benefits

- Differentiation through Ease of Use

- Differentiation by Improved Productivity

- Differentiation by Protecting the Customer's Investment

- Differentiation through Lower Cost of Product Failure

- Differentiation with Higher Performance Products

- Differentiation by Unique Fundamental Capabilities

- Differentiation through Design

- Differentiation based on Standards

- Differentiation by Total Solutions

- Differentiation by Total Cost of Ownership

- Differentiation through Brand Name

- Differentiation based on Convenience

\section{Figure 2}

The Main Dimensions of Differentiation Strategies (McGrath, 1995; McGrath, 2000)

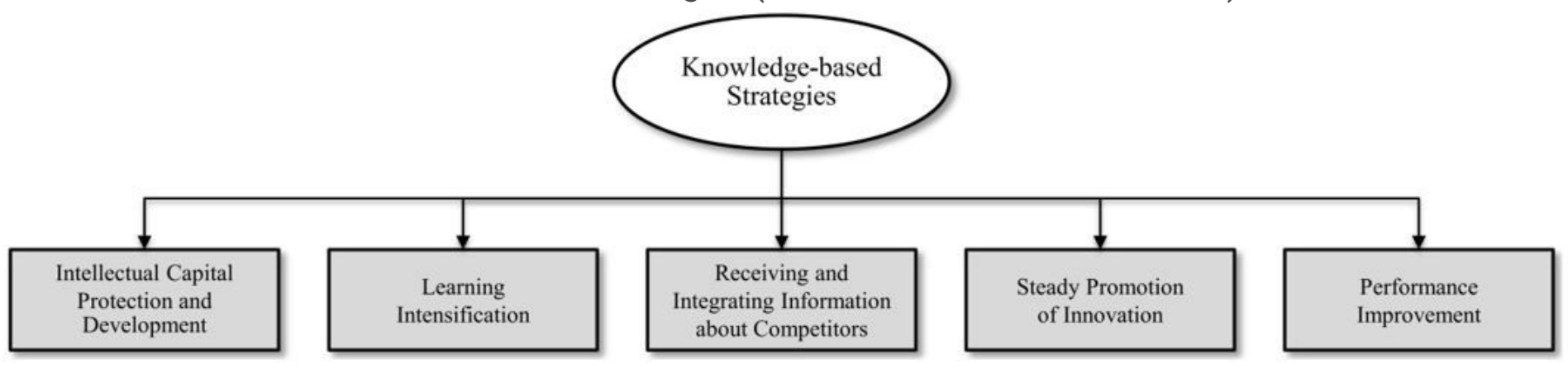

Figure 3

Main Factors in Developing and Implementing Knowledge-based Strategies 


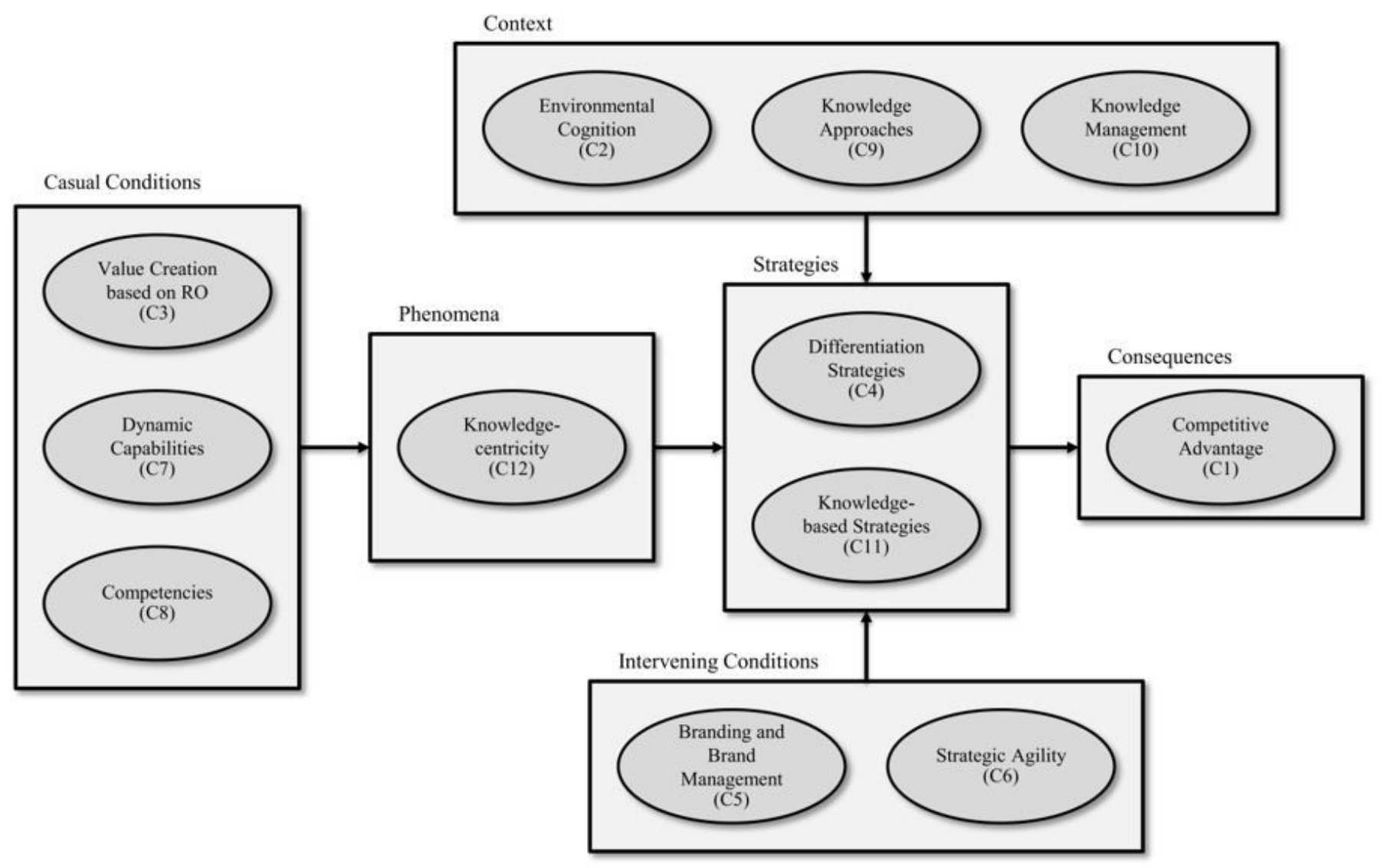

Figure 4

The Extracted Contextual Model of the Research 


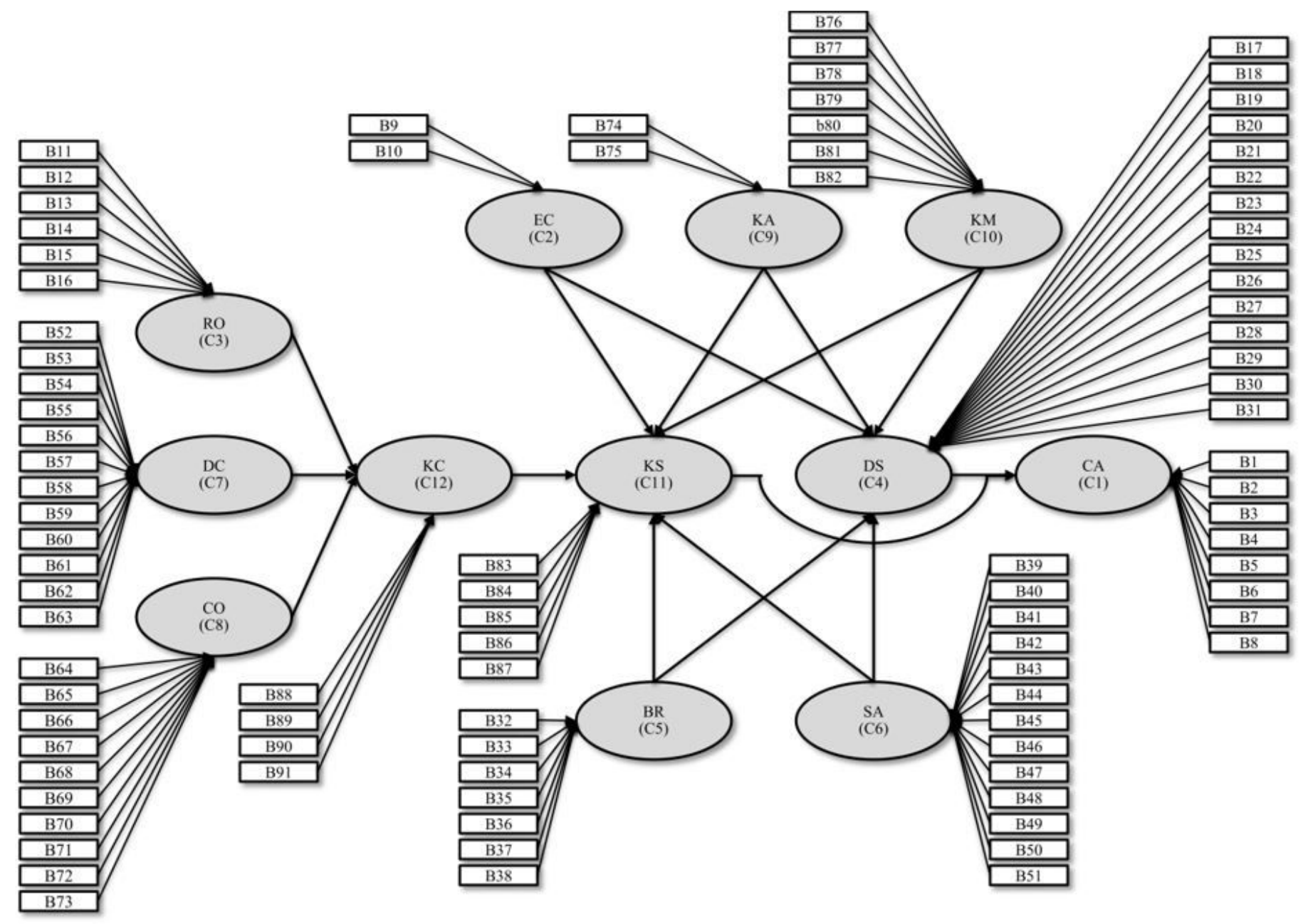

Figure 5

The Extracted Conceptual Model of the Qualitative Research with Constructs and Factors 


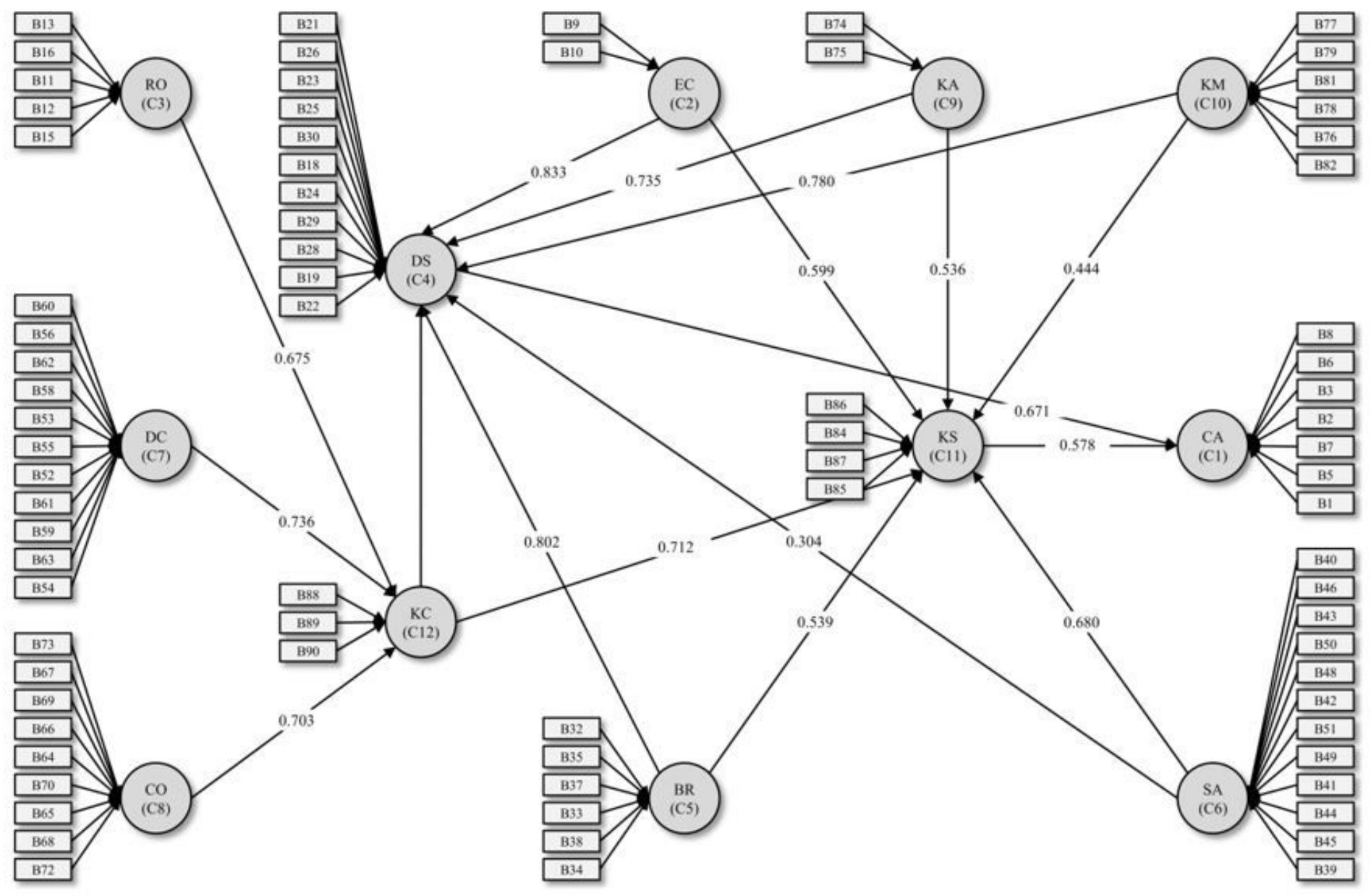

Figure 6

The Final Structural Equations based Model of the Research with Path Analysis through PLS

\section{Supplementary Files}

This is a list of supplementary files associated with this preprint. Click to download.

- JIETables.docx 